\title{
Annex 5
}

\section{Pre-Election and Post-Election Day Joint Appeals with other International Observer Missions}
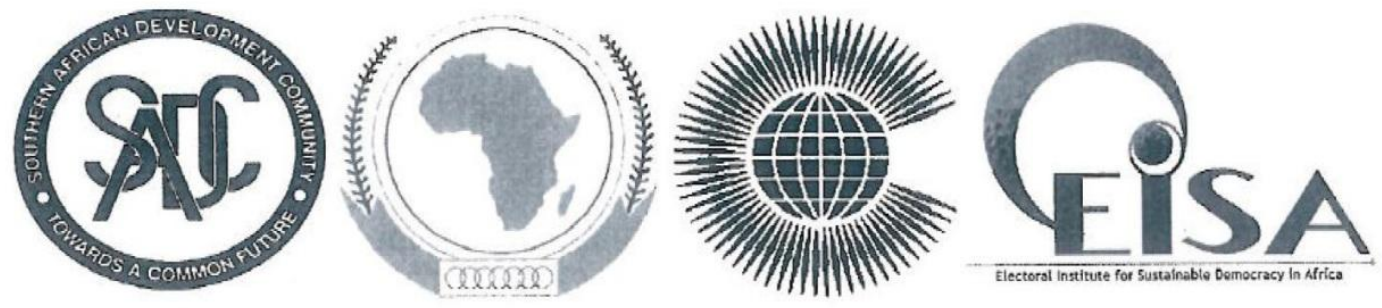

Joint Appeal by SADC, AU, Commonwealth and EISA Election Observer Missions on the eve of the 2012 Lesotho Parliamentary Elections

Maseru, 25 May 2012

1. On Africa Day, within the spirit of the African Union's "Make Peace Happen" Campaign, and on the eve of the 2012 Parliamentary Elections in Lesotho, we, the Election Observer Missions of SADC, AU, Commonwealth and EISA, are delighted to have been invited by the Government, the Independent Electoral Commission and the People of Lesotho to observe and support the electoral process and the consolidation of democracy in Lesotho.

2. We call on all Basotho electors to exercise their democratic right and civic duty and participate massively and peacefully in tomorrow's elections.

3. Having met with all relevant stakeholders and having listened to their views about the process, we call on all stakeholders to ensure that the electoral process is brought to its conclusion in a peaceful manner, and in conformity with the Constitution and other laws of Lesotho, as well other regional, continental and international instruments and standards to which Lesotho has subscribed.

4. We urge all stakeholders to accept the outcome of the elections in the interest of peace, brotherhood, national interest and for the good of Africa.

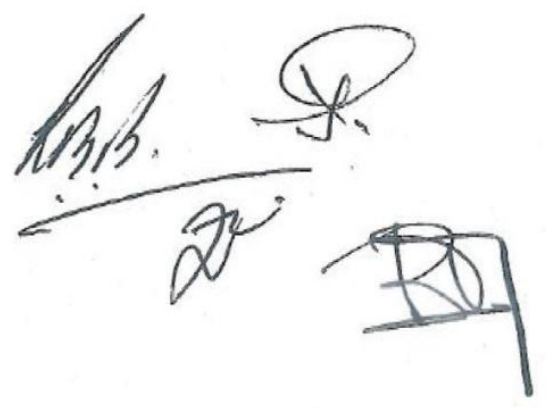


HER EXCELLEX $Y$ Y AMBASSADOR ZODWA LALLIE

HEAD OF THESADC ELECTORAL OBSERVER MISSION

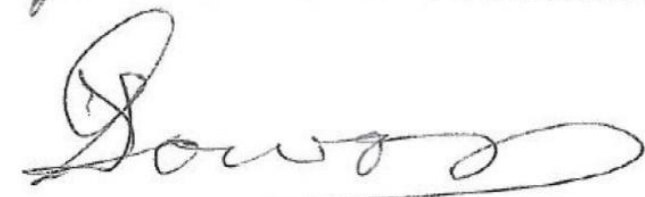

HIS EXCELLENCY GENERAL DR. YAKUBU GOWON

MISSION LEADER OF THE AU ELECTORAL OBSERVER MISSION
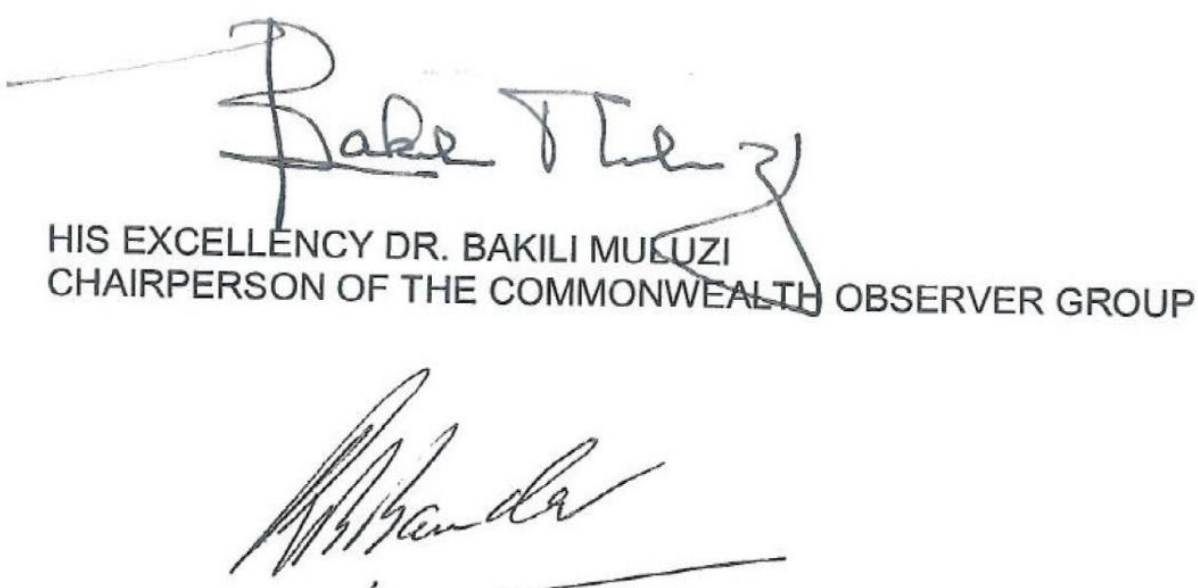

HIS EXCEUEAEYT DR. RUPIAH BANDA

MISSTON LEADER OF THE EISA ELECTORAL OBSERVER MISSION 

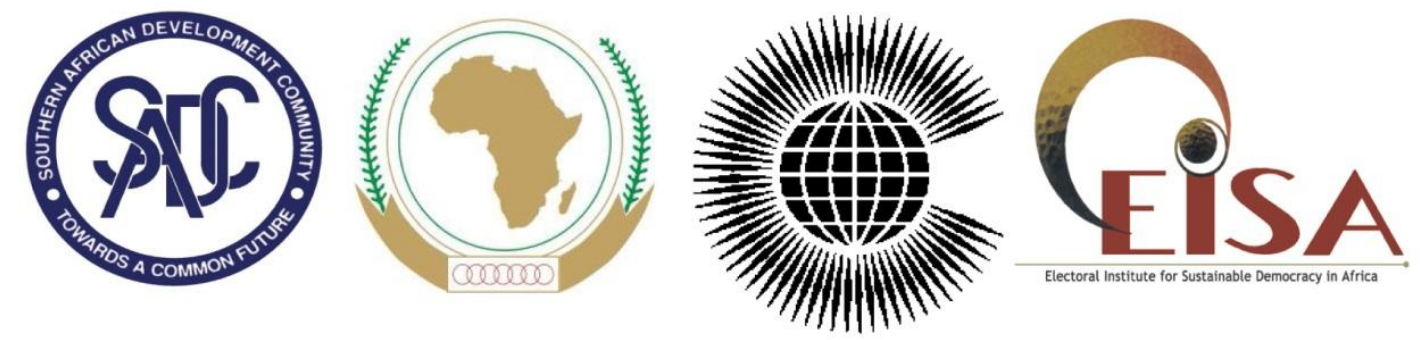

\section{Joint Press Release by SADC, AU, Commonwealth and EISA Election Observer Missions on the 2012 Lesotho Parliamentary Elections}

Maseru, 27 May 2012

The Election Observer Missions of SADC, AU, Commonwealth and EISA to the 2012 Lesotho Parliamentary Elections, headed by Her Excellency Ambassador Zodwa Lallie, His Excellency General Dr. Yakubu Gowon, His Excellency Dr. Bakili Muluzi, and His Excellency Mr. Rupiah Banda, respectively, have observed the voting and counting processes in all ten districts of the country, and are currently following the tallying of results at constituency level.

We are delighted that the voting and counting took place in an atmosphere of peace and tranquility, and that the Basotho electors demonstrated commendable enthusiasm for, and strong commitment to their democratic process by turning out in significant numbers to cast their vote in a peaceful manner.

We would like to commend the Independent Electoral Commission of Lesotho for the professional and efficient manner in which they managed the entire electoral process, in particular the logistics of voting day.

We noted with satisfaction the outstanding and dedicated participation and performance of women and youth as electoral officials and party agents in the polling stations.

We call on all the stakeholders of the Lesotho electoral process to await the conclusion of the process with the same spirit of national unity, peace and solidarity.

We further urge all stakeholders to accept the outcome of the elections with serenity, and in full respect for the Constitution of Lesotho and the democratic process. A special responsibility lies with the political leaders of Lesotho to continue to abide by their preelection commitments to peace.

Each of the four Election Observer Missions will release its individual preliminary statement on the 2012 Lesotho Parliamentary Elections in the coming days. 